\title{
TIDAK DIBAYARNYA UANG PENGGANTI OLEH TERDAKWA TINDAK PIDANA KORUPSI DI PENGADILAN TIPIKOR KUPANG
}

\author{
Oleh : \\ Sepriyanto Thobias Tuka ${ }^{1}$
}

\begin{abstract}
Corruption is an extraordinary crime for causing losses to the state and violate the rights of social and economic communities. The model used is also increasingly diverse and sophisticated. Corruption has resulted in poverty so that the perpetrators of corruption should be subject to punishment for compensation. Due to the corruption that occurred during this time in addition to harming the country also hamper the continuity of national development. The criminal purpose is for the payment of compensation by weighing possible to convict the criminals that they are a deterrent as well in order to restore the state's financial loss due to an act of corruption (refer to Article 18 of Law No. 31 of 1999). The main problem raised in this study is why the failure to apply for compensation to the criminal defendant corruption. The purpose of this study was to determine the cause of the failure to apply for compensation to the criminal defendant corruption. To collect the data required in this study conducted interviews/questionnaires containing gives a list of questions studied in accordance with aspects along with literature. The data obtained in the study processed and analyzed by descriptive qualitative, solving will contain data and documents related to this study. The results of this study are: the judge in his decision not to impose criminal defendant payment of compensation to the corruption because the judges weigh under Article 18 of Law No. 31 of 1999 and one by one element in the provision of primary charges that elements of any person, element unlawfully, the element acts to enrich themselves or someone else or a corporation, or a state financial harm element of the country's economy, the provisions of Article 55 paragraph (1) to-1 of the Criminal Code and the provisions of Article 64 paragraph (1) of the Criminal Code.
\end{abstract}

Keywords: Money Substitutes, State Finance, Corruption.

\begin{abstract}
Abstrak
Korupsi merupakan kejahatan luar biasa karena menyebabkan terjadinya kerugian negara dan melanggar hak-hak sosial dan ekonomi masyarakat. Modus yang digunakan juga semakin beragam dan canggih. Korupsi telah mengakibatkan kemiskinan sehingga pelaku korupsi harus dikenakan pidana pembayaran uang pengganti. Akibat tindak pidana korupsi yang terjadi selama ini selain merugikan negara juga menghambat kelangsungan pembangunan nasional. Tujuan pidana pembayaran uang pengganti adalah untuk memidana dengan seberat mungkin para koruptor agar mereka jera serta dalam rangka mengembalikan keuangan

1 Program Studi Magister (S2) Ilmu Hukum Fakultas Hukum Universitas Udayana, Denpasar, Bali. e-mail : gherekthobyas_tuka@yahoo.co.id.
\end{abstract}


negara yang melayang akibat suatu perbuatan korupsi (menunjuk pada Pasal 18 Undang-Undang Nomor 31 Tahun 1999). Permasalahan pokok yang diangkat pada penelitian ini adalah mengapa tidak diterapkannya pidana pembayaran uang pengganti kepada terdakwa tindak pidana korupsi. Adapun tujuan dari penelitian ini adalah untuk mengetahui penyebab tidak diterapkannya pidana pembayaran uang pengganti kepada terdakwa tindak pidana korupsi. Untuk mengumpulkan data yang dibutuhkan dalam penelitian ini dilakukan wawancara / memberikan kuesioner yang berisi daftar pertanyaan sesuai dengan aspek yang diteliti beserta studi pustaka. Data yang diperoleh dalam penelitian diolah kemudian dianalisis secara deskriptif kualitatif, pemecahan akan berisi data dan dokumen yang berkaitan dengan penelitian ini. Hasil dari penelitian ini antara lain : hakim dalam putusannya tidak menjatuhkan pidana pembayaran uang pengganti kepada terdakwa tindak pidana korupsi karena majelis hakim menimbang berdasarkan Pasal 18 Undang-Undang Nomor 31 Tahun 1999 satu per satu unsur dan ketentuan dalam dakwaan primer yaitu unsur setiap orang, unsur secara melawan hukum, unsur melakukan perbuatan memperkaya diri sendiri atau orang lain atau suatu korporasi, unsur merugikan keuangan negara atau perekonomian negara, ketentuan Pasal 55 ayat (1) ke-1 KUHP dan ketentuan Pasal 64 ayat (1) KUHP.

\section{Kata Kunci : Uang Pengganti, Keuangan Negara, Tindak Pidana Korupsi.}

\section{PENDAHULUAN}

Korupsi merupakan kejahatan luar biasa karena menyebabkan terjadinya kerugian negara dan melanggar hak-hak sosial dan ekonomi masyarakat. Modus yang digunakan juga semakin beragam dan canggih. Oleh karena itu dikeluarkan UndangUndang No.30 Tahun 2002 yang menjadi dasar pembentukan Komisi Pemberantasan Korupsi (KPK) untuk melakukan tugas pemberantasan korupsi di Indonesia. Pemberantasan korupsi tidak dapat dilakukan oleh KPK dan penegak hukum saja, tetapi juga memerlukan sinergi dan kesamaan persepsi dari seluruh komponen bangsa. Di sini, peran serta masyarakat memiliki arti penting dalam strategi pemberantasan korupsi. Pada kegiatan yang sifatnya represif, masyarakat dapat langsung menjadi pelapor dugaan tindak pidana korupsi terutama di birokrasi dan layanan publik sedangkan dari sisi preventif, tindakan utama pemberantasan korupsi dapat dimulai dari kesadaran diri masing-masing untuk mematuhi hukum dan menjauhi tindakan koruptif. Masyarakat pada umumnya anti korupsi, namun pada realitanya sering kali melakukan tindakan yang koruptif atau dimanfaatkan oleh pihakpihak tertentu menjadi lahan korupsi.

Uang pengganti sebagai pidana tambahan dalam perkara korupsi harus dipahami sebagai bagian dari upaya pemidanaan terhadap mereka yang melakukan tindak pidana korupsi. Korupsi telah mengakibatkan kemiskinan sehingga pelaku korupsi harus dikenakan pidana pembayaran uang pengganti akibat tindak pidana korupsi yang terjadi selama ini selain 
merugikan keuangan negara dan perekonomiannegarajugamenghambat kelangsungan pembangunan nasional. Tujuan pidana pembayaran uang pengganti adalah untuk memidana dengan seberat mungkin para koruptor agar mereka jera serta dalam rangka mengendalikan keuangan Negara yang melayang akibat suatu perbuatan korupsi. Salah satu unsur dalam tindak pidana korupsi di dalam Pasal 2 dan 3 Undang- Undang No.31 Tahun 1999 jo Undang-Undang No.20 Tahun 2001 ialah adanya kerugian keuangan negara/perekonomian negara Konsekuensinya, pemberantasan korupsi tidak semata mata bertujuan agar koruptor dijatuhi pidana penjara saja, tetapi harus juga dapat mengembalikan kerugian keuangan negara yang telah di korupsi. Pengembalian keuangan negara diharapkan mampu menutupi ketidakmampuan negara dalam membiayai berbagai aspek yang sangat dibutuhkan.

Menunjuk pada Pasal 18 Undang-Undang No. 31 Tahun 1999 jika terpidana tidak membayar uang pengganti dalam waktu sebulan setelah putusan hakim berkekuatan hukum tetap, harta bendanya dapat disita jaksa dan dilelang untuk menutupi uang pengganti. Jika terpidana tidak mempunyai harta benda yang mencukupi untuk membayar uang pengganti maka dipidana penjara yang lamanya tidak melebihi ancaman pidana pokok. Untuk solusi terhadap masalah ini pernah diusulkan agar di mintakan fatwa Mahkamah Agung yang tujuannya adalah agar ada paying hukum terhadap masalah ini. Pada tahun 2012 dari data pada Pengadilan Tipikor Kupang diketahui telah terjadi 42 kasus korupsi sedangkan pada tahun 2013 meningkat menjadi 45 kasus. Adapun penyebab Pengadilan Tipikor Kupang tidak menjatuhkan pidana pembayaran uang pengganti kepada terdakwa tindak pidana korupsi antara lain :

a. Pengadilan berpatokan pada Undang-Undang terutama unsur pasal yang didakwakan kepada terdakwa.

b. Terdakwa telah mengembalikan uang kerugian milik Negara.

c. Terdakwa tidak menikmati kerugian negara.

Kegagalan dalam pemberantasan tindak pidana korupsi adalah kegagalan dalam penegakan hukum. Efektifitas dalam penegakan hukum ada dua hal yang sangat penting untuk diperhatikan yaitu pertama faktor hukumnya dan yang kedua yaitu faktor penegak hukumnya. Kedua faktor ini yang menentukan efektifitas dalam pemberantasan tindak pidana korupsi. Berdasarkan uraian di atas, penulis dalam hal ini membuat rumusan permasalahan adalah pertama mengapa tidak diterapkannya pidana pembayaran uang pengganti kepada terdakwa tindak pidana korupsi. Kedua bagaimana bentuk sanksi pidana yang diterapkan pada terdakwa tindak pidana korupsi yang tidak membayar uang pengganti. 
Orisinalitas penelitian berdasarkan informasi yang ada dan dari penelusuran yang dilakukan di perpustakaan Universitas, maka penelitian dengan judul Tidak Dibayarnya Uang Pengganti Oleh Terdakwa Tindak Pidana Korupsi di Pengadilan TIPIKOR Kupang. Namun kajiannya belum komprehensif membahas pengaturan serta mekanisme tentang pembayaran uang pengganti oleh terpidana tindak pidana korupsi. Penelitian ini diharapkan berguna memberikan sumbangsih pemikiran dalam upaya pencegahan dan pemberantasan tindak pidana korupsi di Indonesia ke depannya, diantaranya sebagai berikut pertama judul penelitian Efektivitas Pidana Pembayaran Uang Pengganti Dalam Tindak Pidana Korupsi (Studi Putusan Tindak Pidana Korupsi di Pengadilan Negeri Purwokerto) oleh Ade Paul Lukas $^{2}$. Kedua penelitian oleh I Ketut Rai Setiabudhi berjudul Vonis Sanksi Pidana Tambahan oleh Hakim Berupa Pengembalian Kerugian Keuangan Negara oleh Terpidana Tindak Pidana Korupsi di Pengadilan Negeri Denpasar $^{3}$

2 Lukas, A. P. (2010). Efektivitas Pidana Pembayaran Uang Pengganti Dalam Tindak Pidana Korupsi (Studi Putusan Tindak Pidana Korupsi di Pengadilan Negeri Purwokerto). Jurnal Dinamika Hukum, 10(2). doi: 10.20884/1.jdh.2010.10.2.142

3 Setiabudhi, I. (2014). Vonis Sanksi Pidana Tambahan Oleh Hakim Berupa Pengembalian Kerugian Keuangan Negara Oleh Terpidana Tindak Pidana Korupsi Di Pengadilan Negeri Denpasar. Jurnal Magister Hukum Udayana (Udayana Master Law Journal), 3(2). doi:10.24843/JMHU.2014.v03.i02.p05
Aspek kebaruan penelitian penulis adalah bahwa aparat yang melakukan tugas dalam tindak pidana korupsi di sini adalah bertumpu pada peran dan kedudukan Komisi Pemberantasan Korupsi (KPK) sebagai lembaga independen yang memiliki fungsi, tugas, dan kewenangan khusus di bidang korupsi yang berkaitan dengan uang pengganti. Pengaturan tentang tata cara pembayaran uang pengganti korelasinya dalam Peraturan pidana di Indonesia belum tampak baik dalam KUHAP, Undang-Undang tentang pemberantasan korupsi dalam pencegahan dan pemberantasan korupsi hal tersebut penulis sajikan pada rumusan masalah pertama. Pada rumusan masalah kedua tersirat materi yang akan dibahas dikaji terkait dasar pertimbangan pembayaran uang pengganti di masa yang akan datang dalam penyelesaian perkara tindak pidana korupsi.

Peneliti atau penulis-penulis sebelumnya tentang pembayaran uang pengganti dalam tindak pidana korupsi belum tampak memunculkan tindakan KPK dalam melakukan tindakan perampasan aset (penyitaan) koruptor dengan mengaitkan adanya sangkaan terpidana dengan tindak pidana pembayaran uang pengganti dalam kasus pidana korupsi.

Adapun tujuan dari pembahasan dalampenelitianinidapat diuraikandari tujuan umum (het doel van onderzoek) dalam penelitian ini adalah pertama 
sebagai sarana pengembangan ilmu hukum (rechtsbeofening) secara umum ilmu hukum pidana pada khususnya, yaitu tentang tindak pidana atau delikdelik yang tersebar di luar KUHP, yang diantaranya adalah tindak pidana korupsi. Kedua membuka wawasan penulis akan pemahaman lebih luas tentang tindak pidana korupsi dalam konsep kebijakan penegakan hukum khususnya yang berkaitan dengan ide-ide pemikiran bagi pembaruan kebijakan pidana dalam ketentuan tindak pidana korupsi di masa yang akan datang.

Sedangkan yang menjadi tujuan khusus (het doel in onderzoek) dalam penulisan ini adalah untuk mengetahui bagaimana kebijakan penegak hukum dalam tindak pidana korupsi di Indonesia dalam perspektif yang berlaku sekarang (ius constitutum) dan untukmengetahuibagaimanakebijakan penegak hukum dalam arti formulasi terhadap tindak pidana korupsi dalam perspektif, tindak pidana korupsi yang akan datang (ius constituendum).

\section{METODE PENELITIAN}

Karya ilmiah ini menggunakan metode penelitian normatif yaitu penelitian mengenai subtansi hukum yang terdiri dari kaidah asas-asas hukum, doktrin dan peraturan Perundang-Undangan sedangkan yang dimaksud dengan penelitian empiris adalah penelitian mengenai struktur dan budaya hukum. ${ }^{4}$ Dalam penelitian 4 Mukti Fajar dan Yulianto Achmad, 2010 Dualisme Penelitian Hukum Normatif dan ini, konsep-konsep yang berkaitan dengan permasalahan yang diteliti, yang berupa perundang-undangan dan doktrin-doktrin yang berkembang di bidang hukum tindak pidana akan dikaji dengan menggunakan pendekatan konsep (conceptual approach).

Adapun sumber data yang digunakan untuk mendukung penulisan karya ilmiah ini didapat dari dua sumber yaitu Sumber Data Primer: Bahan hukum primer yakni bahan hukum yang terdiri dari aturan hukum yang disusun berdasarkan hierarki. Adapun bahan hukum primer yang digunakan yaitu : perundang-undangan dan peraturan-peraturan lain dalam bidang korupsi yang terkait dengan permasalahan. Sumber Data Sekunder: Bahan hukum sekunder adalah bahan hukum yang diperoleh melalui literatur jurnal, pendapat parah ahli, kasus hukum serta yang digunakan oleh para pakar terkait dengan permasalahan ini. Bahan hukum tersier: Bahan hukum tersier adalah bahan hukum yang memberikan petunjuk atau pejelasan bermakna terhadap bahan hukum primer dan bahan hukum sekunder seperti kamus hukum, ensiklopedi dan lain-lain.

\section{HASIL DAN PEMBAHASAN}

Korupsi merupakan gejala masyarakat yang dapat dijumpai dimana saja. Sejarah membuktikan bahwa hmpir setiap Negara dihadapkan

Empiris, pustaka Pelajar, Yogyakarta, hlm. 28. 
dengan masalah korupsi sehingga pengertian korupsi selalu berkembang dan berubah sesuai dengan zaman. Istilah korupsi berasal dari bahasa latin "corruptus" yang berarti kerusakan atau kebobrokan. Istilah korupsi dari beberapa Negara, dipakai juga untuk menunjukkan keadaan dan perbuatan yang busuk. Korupsi banyak dikaitkan dengan ketidak jujuran seseorang di bidang keuangan. ${ }^{5}$ kerugian yang dapat dibebankan kepada terpidana adalah kerugian negara yang besarnya nyata dan pasti jumlahnya sebagai akibat perbuatan melawan hukum baik sengaja atau lalai yang dilakukan oleh terpidana.

Pasal 18 Undang-Undang RI No. 20 tahun 2001 tentang Pemberantasan Tindak Pidana Korupsi berbunyi sebagai berikut :

1. Selain pidana tambahan sebagaimana dimaksud dalam Kitab Undang-Undang Hukum Pidana, sebagai pidana tambahan:

a. Perampasan barang bergerak yang berwujud atau yang tidak berwujud atau barang tidak bergerak yang digunakan untuk atau yang diperoleh dari tindak pidana korupsi, termasuk perusahaan milik terpidana dimana tindak pidana korupsi dilakukan, begitu

5 Martiman. Prodjohamodjojo. Penerapan Pembuktian Terbalik Dalam Delik Korupsi UU NO. 22 Tahun2001, CV Maudar Maju Bandung. hlm. 6. pula harga dari barang yang menggantikan barangbarang tersebut;

b. Pembayaranuang pengganti yang jumlahnya sebanyakbanyaknya sama dengan harta benda yang diperoleh dari tindak pidana korupsi;

c. Penutup seluruhnya atau sebagian paling lama I (satu) tahun.

d. Pencabutan seluruh atau sebagian hak-hak tertentu atau penghapusan seluruh atau sebagian keuntungan tertentu, yang telah atau dapat diberikan oleh pemerintah kepada terpidana.

2. Jika terpidana tidak membayar uang pengganti sebagaimana dimaksud dalam ayat (1) huruf $b$ paling lama dalam waktu 1 (satu) bulansesudahputusanpengadilan yang telah memperoleh kekuatan hukum tetap, maka harta bendanya dapat disita oleh jaksa dan dilelang untuk menutupi uang pengganti tersebut. Dalam hal terpidana tidak mempunyai harta benda mencukupi untuk membayar uang pengganti sebagaimana yang dimaksud dalam ayat (1) huruf $b$, maka dipidana dengan pidana penjara yang lamanya tidak melebihi ancaman maksimum dari pidana pokoknya sesuai dengan ketentuan dari Undang-Undang 
ini dan lamanya pidana tersebut sudah ditentukan dalam putusan pengadilan.

Salah satu cara untuk mengembalikan kerugian negara yang hilang tersebut adalah dengan memberikan pidana tambahan berupa pembayaran uang pengganti. Upaya ini telah memberikan hasil yaitu berupa pemasukan ke kas negara dari hasil pembayaran uang pengganti dari beberapa terpidana yang telah ditetapkan jumlah pembayaran uang penggantinya. Uang pengganti sebagai pidanatambahan dalamperkara korupsi harus dipahami sebagai bagian dari upaya pemidanaan terhadap mereka yang melanggar hukum. Dalam hal ini hukum yang dilanggar adalah tindak pidana korupsi. Untuk memahami lebih lanjut tentang masalah ini ada baiknya mengingat kembali konsep pemidanaan secara lebih lengkap. Jenis-jenis pemidanaan tercantum di dalam Pasal 10 KUHAP. Jenis-jenis ini berlaku bagi delik yang tercantum diluar KUHP, kecuali ketentuan undang-undang itu menyimpang (pasal 103). Jenis-jenis pemidanaan ini dibedakan antara pidana pokok dan pidana tambahan. Pada prinsipnya pidana tambahan itu hanya dijatuhkan jika pidana pokoknya dijatuhkan. Jenis-jenis pemidanaan itu adalah sebagai berikut :

a. Pidana pokok meliputi : pidana mati, pidana penjara, pidana kurungan, pidana denda, dan pidana tutupan. b. Pidana tambahan meliputi : pencabutan hak-hak tertentu, perampasan barang-barang tertentu, dan pengumuman putusan hakim.

Sanksi pidana yang diatur dalam UU Pemberantasan Tindak Pidana Korupsi yaitu : pidana mati, baik berdasarkan pasal 69 KUHP, UU PTPK maupun berdasarkan hak tertinggi manusia. Pidana mati adalah pidana terberat karena pelaksanaannya berupa penyerangan terhadap hak hidup manusia yang merupakan hak asasi manusia yang utama. Selain itu, tidak dapat dikoreksi atau diperbaiki eksekusi yang telah terjadi apabila di kemudian hari ditemukan kekeliruan. Untuk itu hanya perbuatan pidana yang benar-benar berat yang diancam oleh pidana mati. Pada setiap pasal yang mencantumkan pidana mati selalu disertai alternatif pidana lainnya sehingga hakim tidak serta merta pasti menjatuhkan hukuman mati kepada pelanggar pasal yang diancam pidana mati. Misalnya pidana mati atau penjara seumur hidup atau pidana sementara paling lama 20 tahun sebagaimana tercantum dalam pasal 340 KUHP. Prinsip ini juga diikuti undang-undang lain termasuk undang-undang PTPK. Hukum pidana korupsi merupakan salah satu pidanakhusus. Pidanakhusus yaitu pidana yang pengaturannya secara khusus ditujukan kepada golongan tertentu (seperti militer) atau suatu tindakan tertentu (seperti tindak pidana korupsi). Prinsip pemberlakuan nya adalah hukum pidana khusus lebih 
diutamakan dari pidana umum. Sesuai asas umum hukum yaitu lexgeneralis yang juga diatur dalam KUHP pada pasal 63 ayat (2).

Sebelum mencari tahu apa saja yang melatarbelakangi pembayaran uang pengganti korupsi, terlebih dahulu harus diketahui alasan korupsi dijadikan suatu tindak pidana. Hal ini sangat penting terutama dalam mencari keterkaitan antara perbuatan yang dijadikan tindak pidana dengan sanksi apa yang sebaiknya digunakan. Sehubungan dengan hal tersebut Sudarto mengungkapkan bahwa "Perbuatan yang diusahakan untuk dicegah dan ditanggulangi dengan hukum pidana harus merupakan perbuatan yang dikehendaki yaitu perbuatan yang mendatangkan kerugian (materil dan spiritual) atas warga masyarakat. Hal ini dilakukan untuk kesejahteraan dan pengayoman masyarakat yang harus sejalan pula dengan tujuan pembangunan nasional yaitu mewujudkan masyarakat adil dan makmur". ${ }^{6}$ Terlihat bahwa korupsi telah mengakibatkan pelaku memperoleh keuntungan finansial dan sebaliknya negara sebagai korban menderita kerugian finansial. Pada pokoknya korupsi telahmengakibatkan kemiskinan, sehingga pelaku korupsi harus dikenakan pidana tambahan berupa pembayaran uang pengganti.

Pidana pembayaran uang pengganti, termasuk pidana tambahan yang tercantum dalam pasal 18 ayat (1)

6 Efi Laila Kholis. $O p-c i t$. hlm. 13.
UU PTPK. Pidana tambahan memiliki beberapa perbedaan dengan pidana pokok yaitu :

1. Penjatuhan salah satujenis pidana pokok adalah suatu keharusan atau imperatif. Sedangkan penjatuhan pidana tambahan bersifat fakultatif. Apabila dalam satu persidangan terbukti bahwa terdakwa bersalah secara sah dan meyakinkan maka hakim harus menjatuhkan salah satu pidana pokok sesuai jenis dan batas maksimum dari rumusan tindak pidana yang dilanggar tersebut. Sifat imperatif dapat dilihat pada rumusan tindak pidana, dimana terdapat 2 kemungkinan yaitu diancamkan salah satu pidana pokok sehingga hakim mau tidak mau harus menjatuhkan pidana sesuai rumusan tersebut atau dapat juga tindak pidana yang diancam oleh 2 atau lebih jenis pidana pokok sehingga hakim dapat memilih salah satu saja. Misalnya pada pasal 2 ayat (2) UU PTPK memilih jenis pidana seumur hidup atau selama waktu tertentu antara 4 tahun hingga 20 tahun. Pada pidana tambahan hakim boleh menjatuhkan atau tidak pidana tambahan yang diancamkan terhadap si pelanggar misalnya, hakim dapat menjatuhkan salah satu pidana tambahan pada pasal 18 ayat(1) UU PTPK dalam hal terbukti melanggar pasal $3 \mathrm{UU}$ 
PTPK. Walaupun prinsipnya penjatuhan pidana tambahan adalah fakultatif tetapi terdapat beberapa pengecualian misalnya pasal 250 bis KUHP.

2. Penjatuhan jenis pidana pokok harus bersamaan dengan pidana tambahan (berdiri sendiri) sedangkan penjatuhan pidana tambahan harus bersamaan dengan pidana pokok.

3. Jenis pidana pokok yang dijatuhkan, bila telah mempunyai kekuatan hukum tetap diperlukan pelaksanaan (executie) sedangkan pidana tambahan tidak. Pada pidana pokok diperlukan eksekusi terhadap pencapaian pidana tersebut kecuali pidana pokok dengan bersyarat (pasal 14a) dan syarat yang ditentukan itu tidak dilanggar. Pada pidana tambahan misalnya pidana putusan hakim.

4. Pidana pokok tidak dapat dijatuhkan kumulatif sedangkan pidanatambahandapatdilakukan. Akan tetapi dapat disimpangi pada beberapa undang-undang termasuk UU PTPK.

Definisi pidana pembayaran uang pengganti dapat ditarik dari pasal 18 ayat 1 huruf $b$ Undang-Undang No. 31 Tahun 1999 yaitu : "Uang pengganti yang jumlahnya sebanyakbanyaknya sama dengan harta benda yang diperoleh dari tindak pidana korupsi." Untuk dapat menentukan dan membuktikan berapa sebenarnya jumlah harta benda yang diperoleh dari terpidana dari tindak pidana korupsi jangan hanya ditafsirkan harta benda yang masih dikuasai oleh terpidana pada saat jatuhnya putusan pengadilan tetapi juga harta benda hasil korupsi yang pada waktu pembacaan putusan sudah dialihkan terdakwa kepada orang lain. Pada prakteknya, putusan pidana pembayaran uang pengganti bervariasi besarannya yang dapat disebabkan beberapa faktor antara lain seperti hakim memiliki perhitungan sendiri sebagian hasil korupsi sudah dikembalikan atau tindak pidana korupsi dilakukan oleh lebih dari 1 orang sehingga pidana pembayaran uang pengganti dibebankan bersamasama. Kendala dalam penjatuhan pembayaran uang pengganti dalam rangka penyelesaian keuangan negara pernah diungkap oleh Ramelan adalah:

1. Kasus korupsi dapat diungkap setelah berjalan dalam kurun waktu yang lama sehingga sulit untuk menelusuri uang atau hasil kekayaan yang diperoleh dari hasil korupsi.

2. Dengan berbagai upaya pelaku korupsi telah menghabiskan uang hasil korupsi atau mempergunakan / mengalihkan dalam bentuk lain termasuk mengatasnamakan nama orang lain yang sulit terjangkau hukum.

3. Dalam pembayaran pidana uang pengganti, si terpidana banyak 
yang tidak sanggup membayar.

4. Dasarnya pihak ke-3 yang menggugat pemerintah atas barang bukti yang disita dalam rangka pemenuhan pembayaran uang pengganti.

Masalah penetapan sanksi pidana dan tindakan pada tahap kebijakan legislasi, perumusan ketentuan sanksinya banyak dipengaruhi oleh konsep atau rancangan undangundang yang diajukan ke legislatif. Menurut Barda nawawi Arief, "Strategi kebijakan pemidanaan dalam kejahatan-kejahatan yang berdimensi baru harus memperhatikan hakekat permasalahannya. Bila hakekat permasalahannya lebih dekat dengan masalah-masalah di bidang hukum, perekonomian dan perdagangan, maka lebih diutamakan penggunaan pidana denda atau semacamnya".

Penetapan sanksi hukum pidana seharusnya dilakukan melalui pendekatan rasional. Bila berdasar pada konsep rasional ini maka, kebijakan Penetapan sanksi hukum pidana seharusnya dilakukan melalui pendekatan rasional. Bila berdasarpada konsep rasional ini maka, kebijakan penetapan sanksi dalam pidana tidak terlepas dari penetapan tujuan yang ingin dicapai oleh kebijakan kriminal secara keseluruhan, yakni perlindungan masyarakat. Disebabkan pidana sebagai sarana untuk mencapai tujuan itu, maka haruslah dirumuskan terlebih dahulu tujuan pemidanaan yang diharapkan dapat menunjang tujuan umum tersebut. Kemudian, berorientasi dari tujuan itu untuk menetapkan cara, saran atau tindakan apa yang dilakukan. Tujuan adanya pidana uang pengganti adalah untuk memidana seberat mungkin para koruptor agar mereka jera dan untuk menakuti mereka yang melakukan tindak pidana korupsi. Sudah jelas bahwa korupsi mengakibatkan pelaku memperoleh keuntungan finansial dan sebaliknya negara menderita kerugian secara finansial .

akibat kerugian yang di tanggung negara pada akhirnya berdampak pada berbagai hal. bahkan korupsi telah mengakibatkan kemiskinan, sehingga pelaku korupsi harus di kenakan pidana pembayaran uang pengganti. Akibat tindak pidana korupsi yang terjadi selama ini selain merugikan keuangan negara dan perekonomian nagara juga menghambat pertumbuhan dan kelangsungan pembangunan nasional yang menuntut efisiensi tinggi. Pidana pembayaran uang pengganti memiliki beberapa tujuan mulia. Akan tetapi kontras dengan beban mulia yang diembannya, ternyata pengaturan mengenai pidana uang pengganti justru tidak jelas. Baik UndangUndang No. 3 Tahun 1971 yang hanya mengatur mengenai uang pengganti dalam satu pasal yakni pasal 43 huruf c maupun undang-undang penggantinya Undang-Undang No.31 Tahun 1999 serta perubahannya Undang-Undang No. 20 Tahun 2001 pada pasal 18 minimnya pengaturan mengenai uang 
pengganti mengakibatkan munculnya berbagai permasalahan. Salah satunya adalah dalam menentukan berapa jumlah pidana uang pengganti yang dapat dikenakan kepada terdakwa.

Memang ada kesan akan menimbulkan ketidakadilan bagi terdakwa karena harta bendanya yang diperoleh dari korupsi belum tentu sama banyak dengan kerugian negara yang timbul. Apalagi dalam hal terjadi penyertaan, akan sangat membingungkan berapa harta masingmasing terdakwa yang diperoleh dari korupsi. "Apabila terdakwa atau terpidana membayar uang pengganti, maka jumlah uang pengganti yang dibayarkan tersebut akan diperhitungkan dengan lamanya pidana tambahan berupa pidana penjara sebgai pengganti dari kewajiban membayar uang pengganti”.

1. Terhadap kewajiban pembayaran uang pengganti yang terdakwa nya lebih dari 1 orang supaya di dalam amar tuntutan disebutkan secara jelas dan pasti jumlah kepada masing-masing terdakwa dan tidak boleh disebutkan secara tanggung renteng karena tidak akan memberikan kepastian hukum dan menimbulkan kesulitan dalam eksekusi. Kesulitan eksekusi yang terjadi baik menyangkut jumlah uang pengganti yang harus dibayar oleh masing-masing terdakwa / terpidana maupun terhadap terpidana yang tidak membayar (atau membayar sebagian) uang pengganti sehingga harus menjalani hukuman badan sebagai pengganti dari kewajiban membayar uang pengganti tersebut.

2. Apabila tidak diketahui secara pasti jumlah yang diperoleh dari tindak pidana korupsi oleh masing-masing terdakwa / terpidana, maka salah satu cara yang dapat dipedomani untuk menentukan besarnya uang pengganti yang akan digunakan kepada masing-masing terpidana / terdakwa adalah menggunakan kualifikasi turut serta pasal 55 ayat (1) ke-1 KUHAP.

Untuk pelaksanaan petunjuk penentuan besaran uang pengganti supaya dilaksanakan secara tertib dengan administrasi yang dapat dipertanggung jawabkan disertai bukti-bukti yang akurat yang dapat dipergunakan sebagai bahan pelaporan hasil penyelamatan kerugian keuangan negara oleh kejaksaan agung. Proses pelaksanaan putusan pengadilan secara umum diatur dalam Bab XIX KUHAP. Eksekusi hanya bisa dilakukan dalam hal putusan telah berkekuatan hukum tetap. Eksekusi dilakukan oleh jaksa sebagaimana diatur dalam pasal 1 butir 6 jo pasal 270 KUHAP jo pasal 30 ayat (1) huruf $b$ undang-undang kejaksaan. Pidana pembayaran uang pengganti tidak diatur dalam KUHAP, yang mana pidana ini merupakan salah satu kekhususan PTPK. Dalam hal 
hakim menjatuhkan pidana tambahan berupa pembayaran uang pengganti maka terpidana diberi tenggang waktu sebulan sesudah putusan pengadilan berkekuatan hukum tetap untuk melunasi nya. Jika dalam waktu yang ditentukan tersebut telah habis maka jaksa sebagai eksekutor negara dapat menyita dan melelang barang benda terdakwa (pasal 18 ayat(2) UU PTPK).

Jaksa tidak dapatmemperpanjang batas waktu terpidana untuk membayar uang pengganti seperti pidana denda yang diatur pada pasal 273 (2) KUHAP. Pidana pembayaran uang pengganti dan pidana denda memiliki sifat yang berbeda hal ini dapat dilihat bahwasanya pidana uang pengganti merupakanpidanatambahansedangkan pidana denda merupakan pidana pokok. Menurut Wiryono, walaupun jaksa tidak dapat memperpanjang tenggang waktu pembayaran tetapi mengingat bunyi pasal 18 ayat (2) UU PTPK maka jaksa masih dapat menentukan tahap-tahap pembayaran uang pengganti, tetapi tetap tidak melebihi 1 bulan tersebut. Materi pasal 18 ayat (2) UU PTPK dijumpai kata ". harta bendanya dapat disita dan dilelang......." harta benda yang dimaksud di sini milik terdakwa digunakan maka harta tersebut dirampas dengan menggunakan pidana perampasan sesuai pasal 18 ayat (1) huruf b UU PTPK karena pidana yang dijatuhkan berbeda.
Dalam hal melakukan penyitaan terhadap harta benda terdakwa hendaknya mengikuti tata cara penyitaan yang diatur dalam penerapan eksekusi pembayaran uang pengganti menurut fatwa Mahkamah Agung RI No. 37 / T4 / 88 / 66 / Pid tanggal 12 Januari 1988 yang antara lain :

1. Barang-barang terpidana yang masih ada disita untuk kemudian dijual secara lelang guna memenuhi kewajiban pidana pembayaran uang pengganti;

2. Penyitaan hendaknya dikecualikan atas barang-barang yang diapakai sebagai penyangga mencari nafkah terpidana dan keluarganya,

3. Penyitaan hendaknya menghindari kesalahan penyitaan terhadap barang bukan milik terpidana agar jangan sampai terjadi perlawanan dari pihak ketiga.

Pasal 18 ayat (3) UU PTPK ditentukan dalam hal terpidana tidak mempunyai harta benda yang mencukupi untuk membayar uang pengganti dalam tenggang waktu yang ditentukan ayat (2) maka terpidana dipidana penjara yang lamanya tidak melebihi ancaman maksimal pidana pokoknya dan pidana tersebut sudah dicantumkan dalam putusan. Pidana subsider penjara dalam pasal tersebut terlihat terdapat 3 syarat :

1. Pidana subsider baru berlaku dalam hal terpidana tidak mempunyai harta benda yang 
mencukupi untuk membayar uang pengganti.

2. Lamanya pidana penjara pengganti tidak melebihi ancaman pidana maksimum dari pasal UU PTPK yang dilanggar terdakwa.

3. Lamanya pidana penjara pengganti telah ditentukan dalam putusan pengadilan. Dengan adanya ketentuan tersebut maka juga menjadi kewajiban hakim dalam putusan untuk mencantumkan pidana pengganti ini menghindari apabila uang pengganti tidak dapat dibayar seluruh atau sebagian.

Timbulnya pertanyaan, adilkah apabila terdakwa hanya mampu membayar sebagian uang pengganti (yang mana hal ini sudah termasuk penyitaan dan pelelangan harta benda), karena ketidakmampuannya membayar setengah lagi dia harus melaksanakan pidana penjara subsider seluruhnya. Seperti pada kasus seorang terpidana korupsi dikenai putusan membayar uang pengganti kerugian sebesar Rp. 1 miliar subsider 1 tahun. Namun si terpidana hanya mampu melunasi Rp. 900 juta, sedangkan Rp.100 juta sisanya tidak dapat ditagih karena terpidana tidak mempunyai uang lagi dan tidak punya harta untuk disita. Adilkah bila terpidana itu harus menjalani hukuman badan 1 tahun karena sudah membayar Rp. 900 juta? Dalam kasus seperti ini mestinya dapat menggunakan perhitungan konversi lamanya pidana penjara dengan uang penggantiterpidanakorupsi yangmasih layak dilakukan. Dengan demikian, jika seorang terpidana korupsi hanya mampu membayar setengah uang penggantidapatdikonversikan menjadi setengah pidana penjara subsider yang mesti ditanggung.

Pidana tambahan berupa pembayaranuangpenggantimerupakan kebijakan kriminal yang tidak terlepas dari kebijakan yang lebih luas, yaitu kebijakan sosial (social policy) yang terdiri dari kebijakan untuk mencapai kesejahteraan masyarakat (social walfare) dan kebijakan untuk perlindungan masyarakat (social defence).Oleh karena itu pidana tambahan pembayaran uang pengganti harus dapat ditarik dari terpidana korupsi agar tercapainya kesejahteraan masyarakat. Pidana tambahan pembayaran uang pengganti dari Undang-Undang No. 31 Tahun 1999 yang telah ditambah dan dirubah dengan Undang-Undang No. 20 Tahun 2001 tentang pemberantasan tindak pidana korupsi merupakan tujuan dalam rangka menyelamatkan kekayaan / keuangan negara yang telah diambil oleh pelaku korupsi juga untuk menghukum seberat-beratnya pelaku korupsi.

\section{KESIMPULAN}

Berdasarkan uraian-urian tersebut diatas maka dapat ditarik kesimpulan sebagai berikut pertama hakim dalam menjatuhkan amar putusan tidak menjatuhkan putusan pidana pembayaran uang pengganti 
kepada terdakwa disebabkan karena majelis hakim mempertimbangkan satu per satu unsur dan ketentuan dalam dakwaan primer menurut pasal 18 Undang-Undang Nomor 31 Tahun 1999 yaitu unsur setiap orang, unsur secara melawan hukum, unsur melakukan perbuatan memperkaya diri sendiri atau orang lain atau suatu korporasi, unsur merugikan keuangan negara atau perekonomian negara, ketentuan Pasal 55 ayat (1) ke-1 KUHP dan ketentuan Pasal 64 ayat (1) KUHP. Kedua Alasan terdakwa tindak pidana korupsi tidak mau mengembalikan keuangan negara dalam hal ini membayar uang pengganti kepada negara antara lain : terdakwa tidak menikmati keuangan negara, harta kekayaan terdakwa tidak mencukupi untuk menutupi kerugian negara serta terdakwa telah terlebih dahulu mengembalikan keuangan negara.

\section{DAFTAR PUSTAKA}

\section{BUKU}

Arief, B. N. (2007). Masalah Penegakan Hukum dan

Kebijakan Hukum Pidana dalam Penanggulangan Kejahatan.

Kencana Prenada Media Group. Girsang Juniver. Abuse OfPower, Penyalahgunaan Kekuasaan Aparat Penegak Hukum Dalam Penenganan Tindak Pidana Korupsi. J. G. Publishing

Chazawi, A. (2005). Hukum Pidana Materiil dan Formil Korupsi di
Indonesia. Malang: Bayumedia Publishing.

Hamzah, A. (1986). Korupsi di Indonesia: masalah dan pemecahannya. PbPT Gramedia. Kasawi Adami. Hukum Pembuktian Tindak Pidana Korupsi. Alumni Bandung 2008

Lamintang, P. A. F. (1991). Delik-delik khusus kejahatan jabatan dan kejahatan-kejahatan jabatan tertentu sebagai tindak pidana korupsi. Pionir Jaya.

Marpaung, L. (2005). Asas-Teori-

Praktik Hukum Pidana. Sinar Grafika, Jakarta.

Nawawi, A. B. (2001). Masalah Penegakan Hukum dan

Kebijakan Penanggulangan

Kejahatan. Citra Aditya Bakti, Bandung.

Prodjohamidjojo, M. (2009).

Penerapan pembuktian terbalik dalam delik korupsi: UU No. 20 tahun 2001. Mandar Maju.

TunggalSetiaHadi.(2013).Perundang-

Undangan Pencegahan Dan

Pemberantasan Tindak Pidana

Pencucian Uang dan Korupsi.

Harvarindo Jakarta

Tunggal Setia Hadi. (2013). Undang-

Undang RI No. 46 Tahun 2009

Tentang Pengadilan Tindak

Pidana Korupsi. Citra Umbara, Bandung.

TunggalSetiaHadi.(2013).Perundang-

Undangan Keuangan Negara Terbaru, Harvarindo Jakarta. 
Wiryono R. Pembahasan UndangUndang Pemberantasan Tindak

Pidana Wiyono, R. (2008).

Pembahasan Undang-Undang

Pemberantasan Tindak Pidana

Korupsi. Sinar Grafika.

\section{ARTIKEL JURNAL}

Lukas, A. P. (2010). Efektivitas Pidana Pembayaran Uang Pengganti Dalam Tindak Pidana Korupsi (Studi Putusan Tindak Pidana Korupsi di Pengadilan Negeri Purwokerto). Jurnal Dinamika Hukum, 10(2). doi: 10.20884/1. jdh.2010.10.2.142

Setiabudhi, I. (2014). Vonis Sanksi Pidana Tambahan Oleh Hakim Berupa Pengembalian Kerugian Keuangan Negara Oleh Terpidana Tindak Pidana Korupsi Di Pengadilan Negeri Denpasar. Jurnal Magister Hukum Udayana (Udayana Master Law Journal), 3(2). doi:10.24843/JMHU.2014.v03. i02.p05. 